\title{
Transition period and subclinical ketosis in dairy cattle: association with milk production, metabolic and reproductive disorders and economic aspects
}

\author{
ABDÜLKERIM DENIZ, KEMAL AKSOY*, MERT METIN \\ Department of Biochemistry, *Department of Internal Medicine, Faculty of Veterinary Medicine, \\ Milas, University of Muğla Sıtkı Koçman, 48277 Muğla, Turkey
}

Deniz A., Aksoy K., Metin M.

Transition period and subclinical ketosis in dairy cattle: association with milk production, metabolic and reproductive disorders and economic aspects

\section{Summary}

Many dairy cows experience a high incidence of health problems during the transition period (TP). The TP is an intermediate stage of various digestive, metabolic and reproductive functions which determine the general health status at the time of calving and during the first weeks postpartum. Negative energy balance due to increased energy demand at parturition and significantly reduced dry matter intake relative to demand is an important determinant. Consequently, substantial lipid mobilization from adipose tissue, increased oxidative stress and impaired immunity are associated with higher incidences of periparturient health problems including ketosis or subclinical ketosis (SCK), which have tremendous economic impact on dairy productivity. SCK is defined as the presence of increased blood ketone bodies (BHBA: betahydroxybutyric acid, acetone, acetoacetic acid) without clinical ketosis signs. Varying blood and milk cut-off values have been reported for BHBA concentrations defining SCK, but the most commonly accepted values are $\geq 1.2 \mathrm{mmol} / \mathrm{L}$ and $\geq 200 \mu \mathrm{mol} / \mathrm{L}$ respectively. This underestimated disease can impact dairy cow productivity through decreased milk production in the order of roughly $300 \mathrm{~kg} /$ lactation and increases the risk of metabolic and reproductive diseases such as displaced abomasum, retained placenta, metritis, mastitis, prolong oestrus interval and reduces conception rates. SCK also referred to as 'profit robber or killer' can cause productivity and economic losses of between \$200-290 per dairy cow annually. Options for the control and prevention of SCK include controlled-release monensin capsules, and the injectable combination butaphosphan and cyanocobalamin and oral propylene glycol. SCK is easy to detect in early lactation using cow-side validated BHBA analysers with high specificity and sensitivity.

Keywords: dairy cow, metabolic disease, transition period, subclinical ketosis

The transition period is the most challenging life period of dairy cattle. This period, also known as the peripartum period, consists of the 3 weeks before and after calving. Dairy cattle suffer from an energy imbalance because of an increasing demand for nutrients from the foetus and for milk and colostrum production $(12,38)$. The transition from the pregnant, nonlactating state to the nonpregnant, lactating state is an enormous change and a challenge for metabolic and reproductive functions. A successful transition period primarily determines the productivity of the cow during the next lactation. The energy requirement in early lactation is higher than the energy intake of the cow, which results in a negative energy balance (NEB) (23). During early lactation, almost all dairy cows suffer from NEB, meta- bolic stress, and loss of body condition score (BCS) due to fat mobilisation from the body fat depot in response to increased energy requirements for milk production (25). In many cases, this leads to the development of ketosis which is defined by elevated concentrations of ketone bodies such as acetone, acetoacetate and betahydroxybutyric acid (BHB) in the blood, milk and urine $(13,45)$. Subclinical ketosis (SCK) is manifested as high blood concentrations of ketone bodies without clinical signs $(1,13)$. This is due mainly to NEB in the transition period. In many cases, SCK is defined by a blood $\mathrm{BHB}$ concentration of $\geq 1.0 \mathrm{mmol} / \mathrm{L}-$ $1.4 \mathrm{mmol} / \mathrm{L}(7,15,35,39,50,56,60,62)$. However, the most accepted threshold of blood BHBA for the definition of SCK is $\geq 1.2 \mathrm{mmol} / \mathrm{L}(7,35,60,62)$. Cows 
with signs of clinical ketosis (CK) such as constipation, anorexia, rumen dysfunction, reduced rumination, milk production loss and presence of ketone bodies in the urine (60) had blood BHBA concentrations of $\geq 1.4 \mathrm{mmol} / \mathrm{L}(15),>2.0 \mathrm{mmol} / \mathrm{L}(52),>2.9 \mathrm{mmol} / \mathrm{L}$ (64) and $>3.0 \mathrm{mmol} / \mathrm{L} \mathrm{(45)} \mathrm{in} \mathrm{the} \mathrm{first} \mathrm{and} \mathrm{second}$ week of lactation. More recent reports indicate that the average prevalence of SCK worldwide is between $21-24 \%$ (from minimum $8 \%$ to maximum $46 \%$ ) based on blood levels of BHBA $(7,62)$. SCK is associated with various production parameters. These are milk production loss, metabolic and reproductive disorders such as displaced abomasum (DA), retained placenta (RP), metritis, mastitis, prolonged oestrus interval, low conception rate, cystic ovaries, long open period and culling $(7,13,34,35,49,62)$. Production loss due to SCK and associated disorders in dairy farms has been estimated at \$200-290 per cow $(18,36,37,43,46,48)$. SCK has also been called 'a silent profit robber' (9) or 'an underestimated profit killer' (6) because of this production loss and associated disorders. The objective of the present review is to discuss the latest information about the transition period, SCK and associated metabolic, reproductive disorders and their economic impact as well as prevention and treatment options in dairy cattle.

\section{The transition period}

The transition period (TP) between late pregnancy and early lactation also known as the periparturient period consists of around 3 weeks before and after parturition $(12,23)$. It is possibly the most challenging and difficult stage in the life of a dairy cow. Opinion differ about the timing of TP. McGuffey (38) defines $\mathrm{TP}$ as the time from day 10-14 before calving to day 4-6 after calving. Drackley (12) compared this critical period to the ancient Chinese curse, "May you always live in interesting times". In practical terms, this means that the transition cow experiences a difficult and challenging time because of the many infectious, metabolic and reproductive diseases that occur during this time. Milk fever, ketosis, SCK, RP, metritis, mastitis and DA predominantly affect cows during TP $(12,13)$. Dairy cows experience TP as a matter of course in order to give birth and produce milk every year in essence a vicious cycle. In this context, important physiological, nutritional, reproductive, metabolic, and immunological changes occur within this time frame. Cows must adjust metabolically and physiologically to the significant increase in energy and nutrient requirements needed to ensure milk production in early lactation $(3,4)$. According to Bell (4), cows producing $30 \mathrm{~kg}$ milk daily need 2 times more amino acids, 4.5 times more fatty acids, and 2.7 times more glucose for lactation on day 4 postcalving than on day 4 precalving. This alone is a tremendous metabolic challenge for a dairy cow in TP which is unavoidable in order to support a new physiological stage after calving (3) for milk production, uterus involution and upcoming conception. Increased energy demands for the development of the foetus in the late pregnancy and for the production of milk in early lactation together with decreased dry matter intake (DMI) at calving lead to NEB, insulin resistance, lipid mobilisation, and loss of BCS in dairy cows $(30,32)$. There is a significant increase in udder glucose utilisation, primarily for lactose synthesis at the start of lactation. This makes glucose an important molecule during the biological adaptation to early lactation. High-yielding cows can utilise up to $3 \mathrm{~kg}$ glucose per day, with up to $85 \%$ of that utilised by the mammary glands. Lactose synthesis in the mammary glands utilises 65 to $70 \%$ of the cow's total glucose requirement (3). If there is an imbalance between the availability and demand for glucose at calving and early lactation, ketosis occurs to provide an adequate glucose supply for the lactation. This process includes gluconeogenesis, decreased glucose uptake and use by adipose tissue and muscle, and a shift in whole-body nutrient oxidation so less glucose is used as an energy source (3), ultimately resulting in NEB. Reduced DMI relative to requirements starting just before parturition indicates the importance of lipid metabolism in transition cows. DMI starts dropping especially during the last 2 to 4 days before parturition and feed intake may be as low as 0 to $4 \mathrm{~kg}$ at parturition (38). In order to meet energy requirements, large amount of lipids mobilized from adipose reserves deliver non esterified fatty acids (NEFA) to the blood which are associated with higher incidences of postpartum disorders (12) as well as higher circulating ketone bodies in later stages $(30,32)$. As a result of lipid mobilisation due to NEB in TP, plasma NEFA and BHBA concentrations increase and plasma triglycerides (TG) and glucose concentrations decrease between prepartum and day 4 to 28 postpartum. In contrast, liver TG content was significantly higher on days 4 and 14 postpartum (2). The liver plays an important role in dealing with the high influx of NEFA from the blood to meet the associated higher energy demand $(30,32)$. In this context, the mitochondrial and peroxisomal oxidation of NEFA has a central role through catabolic enzymes (30). If the liver is overloaded through higher influx of NEFA, fatty acids are esterified to TG and stored in the hepatocytes which can result in fatty liver syndrome, unless TG are excreted from the liver as very-low-densitylipoproteins (VLDL) $(12,25,30)$. Recent research on blood fructosamine concentration in the first month of lactation showed a positive correlation with concentrations of plasma glucose and albumin. The plasma fructosamine level during the first 3-4 weeks of lactation was a predictor for the energy balance in the transition period (8). NEB was more influenced by DMI and inflammatory conditions than the high milk production (8). The cow must receive enough energy, protein, vitamins, and minerals for colostrum and milk production at a time when DMI is dropping (38). Transition 
of the cow from the pregnant-nonlactating stage to the nonpregnant-lactating stage with reduced DMI and NEB (Fig. 1) increases the risks of various health disorders, including mastitis, metritis, SK, CK, displaced abomasum, prolonged oestrus interval and low conception rate $(34,46,69)$. Calving also creates large abdominal space that increases the risk for DA (38). These metabolic, reproductive and infectious diseases that compromise the cow's health may lead to culling or death $(32,38,49$, 59, 64). Figure 1 illustrates the TP of dairy cattle including potential problems, physiological changes and lactation stages.

A recent study (69) reported the incidence of health problems from 5 dairy farms in Michigan in cows clinically healthy at

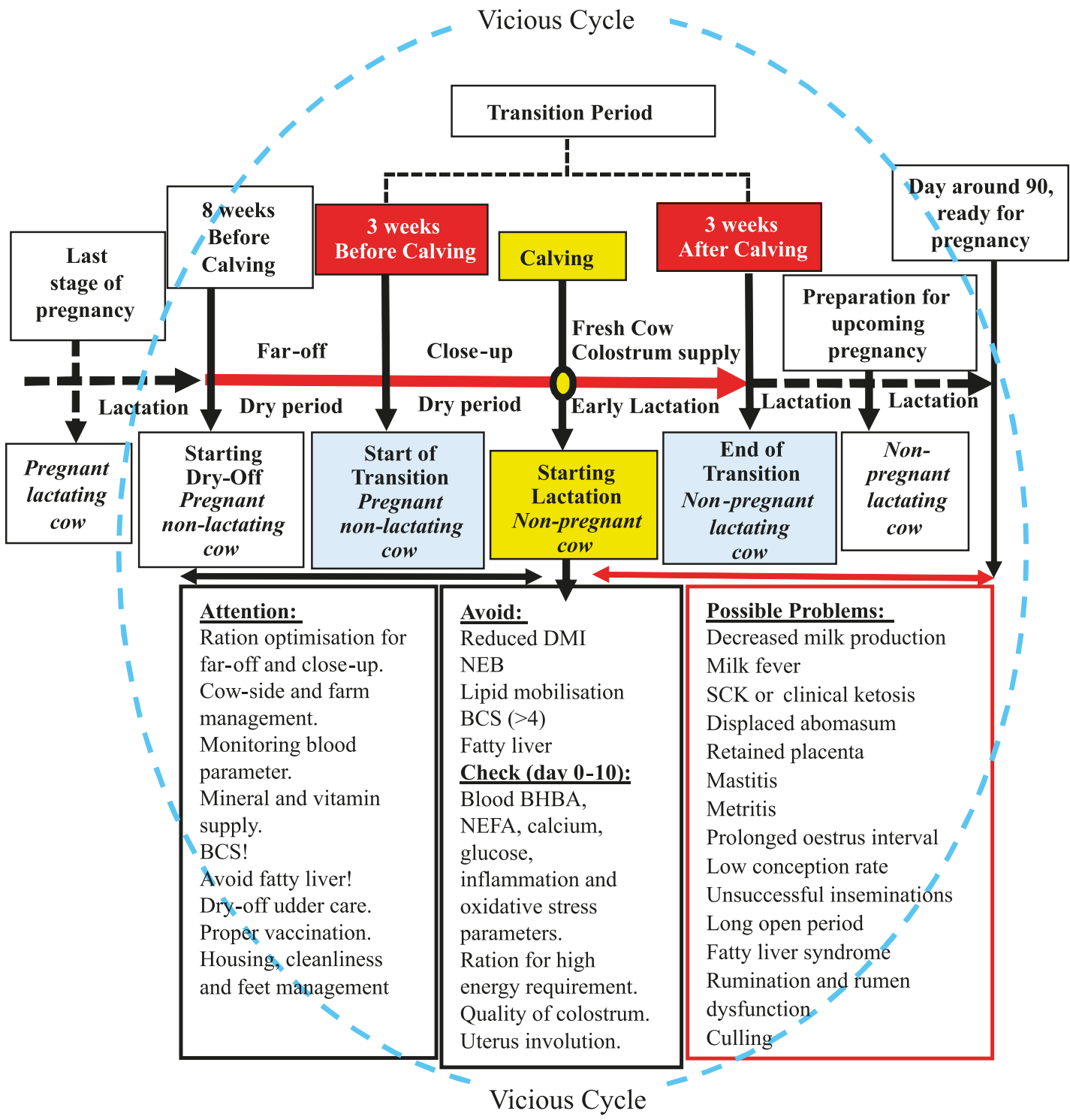

Fig. 1. Critical life cycle periods of dairy cattle including transition period: a vicious cycle the time of drying-off. Various diseases such as ketosis $(7.9 \%)$, metritis $(7.2 \%)$, lameness $(6.8 \%)$, RP $(6.5 \%)$, mastitis (5.4\%), DA (2.5\%), abortion (1.4\%), milk fever $(1.1 \%)$ and death $(1.4 \%)$ were observed in a total 277 cows (68\% multiparous) up until day 30 postpartum. The overall incidence of having at least one disease and/or adverse outcome was $33.6 \%$. Previous studies conducted by Jordan and Fourdraine (27) 26 years ago in 61 dairy farms recorded slightly higher incidences of postpartum disorders in dairy cows, of $7.2 \%$ milk fever $(0-44.1 \%), 9 \% \mathrm{RP}(0-22.9 \%), 3.3 \% \mathrm{DA}(0-14 \%)$, $3.7 \%$ ketosis $(0-20 \%), 12.8 \%$ metritis $(0-66 \%), 13 \%$ cystic ovarian (0-58.8\%) and $12.8 \%$ uterus infection $(0-66 \%)$. The reason for these difference might be improved herd and TP management and better feeding strategies for drying-off and early lactation developed in the last 26 years. Increased metabolic and oxidative stress and impaired immune function $(33,40,46,47$, 63 ) are responsible at some extent for the increased disease incidences during the postpartum period. High concentration of NEFA and BHBA can have significant impact on the immune function, especially on white

blood cells $(33,40)$. Insufficient antioxidant defence mechanisms are not able to cope with the increasing generation of reactive oxygen metabolites resulting in oxidative stress. NEB, elevated concentration of NEFA, BHBA and haptoglobin can impair the oxidative status which can be associated with peripartum diseases $(46,63)$. Cows with greater serum reactive oxygen metabolites and lower ferric reducing ability had a greater index of oxidative status and lower milk yield $(-7 \%)$ in the 100 day period postpartum. Those cows also had a 1.4-fold increase in serum BHBA concentration (63). Physiological parameters of immunity, oxidative status and inflammation biomarkers of healthy dairy cows were measured on day 6 before drying-off, at the drying-off and on days 1, 2, 6 and 12 after the drying-off (47). Inflammation parameters and indicators of oxidant status such as haptoglobin, reactive oxygen and nitrogen species, antioxidant potential, and oxidant status index increased during the transition from late lactation into the early dry period (47). The transition from late lactation stage to the dry period and associated feeding changes in far-off, 
close-up, calving, early lactation are challenging moments which result in a vicious cycle of metabolic and oxidative stress throughout the lifetime of dairy cattle (Fig. 1).

\section{Subclinical ketosis (SCK)}

SCK is manifested by increased ketone bodies (such as BHBA) in the blood and milk without signs of CK $(1,5,13$, 14). This elevated concentration is a result of high lipid mobilisation and consequently progressive ketogenesis in the liver $(12,30)$. However, this silent disease is still harmful in terms of metabolic and reproductive health and milk production $(11,14,32,41,49,55,56,59,62,64)$. This insidiously and progressive disorder causes economic losses $(13,18,36,43,45)$, to the significant degree that it is described by some authors as a silent profit robber (9) or an underestimated profit killer (6). Roche et al. (52) described 3 different types of etiological reasons for the development of ketosis in cows. The first is spontan ketosis due to reduced DMI at calving which results in lipid mobilisation, the second is in cows that are obese or fat at the time of calving $(\mathrm{BCS}>4)$ having been high energy feed at dry-off and the last is silage ketosis; caused by cows consuming poor-quality silage. Silage that has undergone secondary fermentation can increase blood BHBA concentrations and the risk of ketosis. Clinical ketosis is define by elevated blood BHBA concentration and signs of reduced rumination, rumen movement, and milk production, as well as constipation, anorexia and the presence of ketone bodies in the urine (60). Ketone bodies originate from beta-oxidation of large amounts of NEFA generated as a result of lipid mobilisation to compensate the energy requirement $(39,52)$. Beta-oxidation is a process where NEFA generated as a result of lipid mobilisation in the mitochondria or peroxisomes to generate acetylCoA, which then enters the tricarboxylic acid cycle as well as being used for the production of NADH and $\mathrm{FADH}_{2}$, mainly used by the electron transport system. Acetyl-CoA produced in excess can then be used for the biosynthesis of acetoacetyl-CoA and $\beta$-hydroxy$\beta$-methylglutaryl-CoA (30), resulting in the formation of acetoacetate, BHBA and acetone known as ketone bodies. Ketone bodies are important sources of energy which are transported from the liver to peripheral tissues, especially during fasting or reduced DMI, when glucose supply is reduced. Generally blood concentration of ketone bodies have been evaluated together with those of glucose and NEFA (46). There are certain metabolic predictors that are often used to monitor the metabolic status of the transition cow such as blood concentrations of BHBA, NEFA, glucose, calcium, BCS and parity (primiparous and multiparous) $(17,32$, $46,54,69)$. However, there is currently no practical validated device for cow-side testing of blood NEFA concentration available for use on farms. In contrast, there are several validated devices with high specificity and sensitivity for cow-side testing of blood BHBA $(7,26,30,60,62)$. Obese dairy cows $(\mathrm{BCS} \geq 3.75)$ in the prepartum period have a higher risk for ketosis and DA. Cows with a moderate (3.25-3.75) or fat $(\geq 4)$ BCS prepartum have a higher risk of developing SCK and $\mathrm{CK}$ than thin cows $(\mathrm{BCS} \leq 3.0)(59,66)$. The risk for developing SCK is higher in multiparous than primiparous cows $(7,14,27,66)$ and cows with SCK had reduced rumination than healthy cows $(28,58)$, which could then be the reason for reduced DMI. SCK is defined by the absence of clinical signs and a blood BHBA concentration threshold of $0.96 \mathrm{mmol} / \mathrm{L} \mathrm{(50),}$ $1.0 \mathrm{mmol} / \mathrm{L}(13,39,56,68)$ or the most accepted level of $\geq 1.2 \mathrm{mmol} / \mathrm{L}(1,7,14,16,62,60,64)$. However, there are a few studies that report a threshold of serum $\mathrm{BHB}>1.4 \mathrm{mmol} / \mathrm{L}$ (13). Other diagnostic tests used commonly on farm to define SCK include milk BHBA testing using strips $(5,39)$ or fourier-transform infrared spectrometry (57). The most accepted threshold to define SCK for milk BHBA is $\geq 200 \mu \mathrm{mol} / \mathrm{L} \mathrm{(39}$, 46, 57). Figure 2 shows metabolic and reproductive interactions associated with SCK.

\section{Prevalence of SCK}

Duffield (13) reported that hyperketonaemia was mostly seen in the first 2 weeks postpartum, which is consistent with reports from Duffield et al. (14), McArt et al. (35) and McGuffey (38), while Dohoo and Martin (11) observed that the peak prevalence of ketosis determined by milk testing occurred in the third and fourth week of lactation. Recent studies have looked at the prevalence of SCK using a blood BHBA threshold of $\geq 1.2 \mathrm{mmol} / \mathrm{L}$ on days $2-21(7,14), 14-21$ (60), 2-15 (62), 14-21 and 6 weeks (64) postpartum. 
A large scale multicentric study was conducted in 10 European countries (Italy, Germany, Turkey, Croatia, Serbia, Poland, Slovenia, Hungary and Spain) and reported an average prevalence of $21.8 \%$ in 528 dairy herds with a total of 5,884 dairy cattle enrolled (62). Another study (7) showed an average prevalence of 24\% in 12 countries worldwide (Argentina, Australia, Brazil, Chile, China, Colombia, Mexico, New Zealand, Russia, South Africa, Thailand, and Ukraine). The highest prevalence worldwide has been reported in Italy (36.6\%) (62) and New Zealand (40.1\%) (7). However, Berge and Vertenten (5) reported an average prevalence of $39 \%$ in European countries $(43 \%$ in Germany, $53 \%$ in France, $31 \%$ in Italy, $46 \%$ in the Netherlands, and $31 \%$ in the United Kingdom) using a threshold of $\geq 100 \mu \mathrm{mol} / \mathrm{L}$ BHBA in milk between days 7-21 postpartum which is lower than that used by others of $\geq 200 \mu \mathrm{mol} / \mathrm{L}(39,46,57)$. A large study was conducted in Canada (498,310 Holstein cows in 4,242 herds) using Fourier-Transform Infrared Spectrometry with a milk BHBA cut-off-point of $\geq 200 \mu \mathrm{mol} / \mathrm{L}$ which reported a prevalence of $22.6 \%(57)$. The cut-off points are a determining factor for the result. The cut-off point of the respective parameter (milk or blood BHBA) needs to be taken into account when interpreting the prevalence results for SCK or any other disease if they are to be evaluated together.

\section{Milk production losses associated with SCK}

A negative effect on milk production in dairy cattle associated with SCK has been reported by various authors $(11,13,14,24,41,46,49,56)$. Cows with blood BHBA $\geq 1.4 \mathrm{mmol} / \mathrm{L}$ to $2.0 \mathrm{mmol} / \mathrm{L}$ without clinical signs in the first week postpartum had reduced milk production of between 1.4-4.2 kgs/day (13). This elevated blood BHBA in the first week postpartum can result in milk losses of between 427-1,281 kg over 305 milking days. Calculated milk production losses over a lactation due to SCK have been reported as $328 \mathrm{~kg}$ (24), 305-427 kg (11), $390 \mathrm{~kg}$ (46) and $251 \mathrm{~kg}(49)$. Şahal et al. (56) reported that cows with SCK (average blood BHBA at $1.25 \mathrm{mmol} / \mathrm{L}$ on days $7-15$ postpartum) not treated with an injectable butafosfan and cyanocobalamin combination $(\mathrm{B}+\mathrm{C})$, produced $4.7-7.4 \mathrm{~kg}$ less milk daily over 30 days postpartum, compared with treated animals. In this study, there might be an additional positive effect of phosphorus and vitamin $B_{12}$ on the milk production beside of reduced SCK incidence.

\section{Culling, metabolic and reproductive disorders associated with SCK}

It is widely accepted that SCK reduces milk yield, metabolic and reproductive performance and increases the risk of culling in dairy cow husbandry $(15,36$, $59,67)$. SCK may lead to culling of dairy cattle due to impaired production parameters $(13,49,51,64)$. In fact, a NEFA concentration of $\geq 0.4 \mathrm{mmol} / \mathrm{L}$ at one week pre-calving and an elevated blood BHBA of $\geq 0.7 \mathrm{mmol} / \mathrm{L}$ were highly associated with an increased rate of culling with an odds ratio of 1.8 times likelihood within 60 days post-calving. Higher blood concentrations of NEFA $(\geq 0.8 \mathrm{mmol} / \mathrm{L})$ and BHBA $(\geq 1.2 \mathrm{mmol} / \mathrm{L})$ at one week post-calving were also significantly correlated with an increased culling rate within 60 days postpartum (odds ratio: 2.0 and 1.8 times respectively) (51). Correlation of SCK with an increased culling risk has been reported by others as well, cows with SCK were 3.6 times (4), 1.92 times (49) more likely to be culled and $26.4 \%$ of cows with SCK was culled (64). Culling on high milk producing dairy farms was mainly due to reproductive and metabolic disorders $(22,42,65)$. Ülker and Bakir (65) reported a culling rate of $22.6 \%$ due to reproduction problems in high milk producing dairy farms. DA is the most frequently observed metabolic disorder associated with SCK in the first weeks postpartum with a risk factor of 4-13.6 times more likely $(14,15,34$, $46,62,59)$. Creation of a large abdominal space after calving (38) and an unfilled rumen due to reduced DMI at parturition is possibly the most important reason for DA. Transformation of SCK into CK was frequently observed with a risk factor of 4-10.5 times more likely $(14,15,46,59,62)$. Prevalence studies in Europe and around the world have reported a 1.8 times higher rate of lameness incidence associated with SCK (62), and $1.8 \%$ incidence in subclinically ketotic cows (7). The time between calving and uterus involution has been described by Shelton (61) and it can take up to 40 days. $83-88 \%$ of multiparous dairy cattle diagnosed with SCK on day 7-15 postpartum and treated with $B+C$ had complete uterus involution within 25 days after calving when compared to untreated cows (44\%) with SCK (blood BHBA of $1.25 \mathrm{mmol} / \mathrm{L}$ ) (56). A significant increase in the risk of metritis associated with SCK has also been reported by various authors, $25 \%$ (64) and $5.3 \%$ (7). On the other hand, risk factors of $3.3(15)$, $1.7(62),>4(46)$ and 4.7 (69) times were calculated for metritis in cows with SCK. In association with the metritis and delayed uterus involution described above, $\mathrm{RP}$ is a frequently observed reproductive disorder $(7,34,59,62)$ in SCK. Suthar et al. (62) did not establish a threshold for blood BHBA in RP and milk fever because these diseases are observed just $2472 \mathrm{~h}$ postpartum; nevertheless a risk factor of 2.4 times (milk fever) and 2.5 times (RP) likelihood has been reported. In accordance with this, Seifi et al. (59) indicated a risk factor of 4.7 times and Brunner et al. (7) reported a $4.8 \%$ incidence of RP. Cystic ovarian disease associated with SCK has been observed at a rate of $13.5 \%$ (27) and $1.7 \%$ (67) and 5.6 times more likely (11) in dairy cows. Cattle with blood BHBA $>1400 \mathrm{mmol} / \mathrm{L}$ were more susceptible to developing severe mastitis in an experimental E. coli study (31). Mastitis occurrence related to SCK has been reported in a number of studies $(7,14,49,64)$. Frequency of SCK associated mastitis was 1.6 times higher (49) and an incidence of $3.4 \%$ 
across 12 countries (7) was reported. Suthar et al. (62) did not find a significant correlation between mastitis incidence and SCK. High concentration of NEFA and BHBA can have a significant impact on the immune function, especially on white blood cells $(33,40)$. On the other hand, impaired oxidative status in transition cows $(46,47,63)$ may be an important reason for increased postpartum infections. The number of days open associated with SCK has been reported as 130 days (67), 95 days (56). In line with this, the average number of artificial inseminations increased to 2.8 (55) and 2.0 (56), and consequently the conception rate was reduced by $15 \%$ (46) and $20 \%$ (67). Thus, the time taken to get pregnant after calving was prolonged by 16-22 days (49) and 8-15 days (56).

\section{Estimated economic impact and prevention of SCK}

There are several studies reporting the economic impact of SCK in dairy husbandry associated with lost milk production, treatment of diseases, reproduction losses and culling $(13,18,36,37,43,48,49)$. Ghoary et al. (18) reported a negative effect of SCK on dairy herd economics in Canada of $\$ 203$ per cow. The largest part $(35 \%)$ of this cost attributed to SCK was due to clinical diseases such as CK, DA and metritis, but reproduction problems, milk production loss and culling/death also contributed $28 \%, 22 \%$ and $13 \%$ respectively. A Study from the Netherlands (43) reported a similar annual loss of $€ 130$ per cow, $€ 83$ per $1^{\text {st }}$ parity cow and $€ 175$ per $3^{\text {rd }}$ parity cow. Thirty-six $\%$ of costs were accounted to a prolonged calving interval, $24 \%$ to reduced milk production, $19 \%$ to treatment of clinical diseases, $14 \%$ to discarded milk and $6 \%$ to culling. Based on the milk production loss associated with SCK over $305 \mathrm{~d}$, the calculated total cost of SCK was $€ 257 /$ cow attributed to various SCK related diseases like early culling, DA, $\mathrm{RP}, \mathrm{CK}$, prolonged calving interval, mastitis, metritis and lameness (48). In contrast, the cost of hyperketonaemia in early lactation cattle was calculated at \$289 per cow (37), mainly associated with reproduction losses $(34 \%)$, future milk production loss and death $(26 \%)$, culling $(6 \%)$ and other causes $(6 \%)$.Use of in-feed ionophores (monensin) on two dairy farms reduced the incidence of SCK by $50 \%$ which reduced the associated cost by CAN $\$ 50-100$ per cow per lactation (13). Monensin (13, 16, 21, 39), propylene glycol (PG) $(20,36)$, and injectable $\mathrm{B}+\mathrm{C}(19,20,44,53,56)$ are some useful options to reduce the economic impact of subclinical ketotic cows. Cows in their $2^{\text {nd }}$ lactation with mean blood BHBA concentrations of between 1.76 and $2.15 \mathrm{mmol} / \mathrm{L}$ (SCK) on days 7-15 postpartum and treated with two dose-rates of injectable $\mathrm{B}+\mathrm{C}$ $(5-10 \mathrm{ml} / 100 \mathrm{~kg})$ for 4 consecutive days had an increase of total milk production $(139-223 \mathrm{~kg}$ ) in the first 30 day postpartum compared to control cows (mean blood BHBA of $1.25 \mathrm{mmol} / \mathrm{L}$ ) and a significant decrease of blood BHBA within 1-2 weeks (56). To some extent in agreement with these results, ketotic cows in their $3^{\text {rd }}$ lactation with blood BHBA $\geq 1.2 \mathrm{mmol} / \mathrm{L}$ and glucose $\leq 2.2 \mathrm{mmol} / \mathrm{L}$ in the 3-16 days postpartum, were treated with lower dosages of injectable B+C (25 ml per cow subcutaneously) for 3 consecutive days which increased milk production by $2.8 \mathrm{~kg} /$ day and $3.1 \mathrm{~kg} /$ day without any effect on blood BHBA $(19,20)$. Significant decreases of blood BHBA in subclinically ketotic cows treated with injectable $\mathrm{B}+\mathrm{C}$ has been reported by others $(9,10,44,53,56)$, while Gordon et al. $(19,20)$ did not report a significant effect. The dosage and application route used in the study of Gordon et al. $(19,20)$ differed from other studies in that $B+C$ was given intravenously at $10 \mathrm{ml} / 100 \mathrm{~kg}$ for 3 days (44) and intramuscularly at $5-10 \mathrm{ml} / 100 \mathrm{~kg}$ for 4 days (9). Rollin et al. (53) found a similar significant effect of injectable $\mathrm{B}+\mathrm{C}$ on blood $\mathrm{BHBA}$ which has been used in a dosage of $25 \mathrm{ml}$ subcutaneously at calving and 1 day later in SCK-cows with lactation number $\geq 3.0$. Use of an intraruminal controlled release capsule (CRC) of monensin (delivering $335 \mathrm{mg} /$ day) 3 weeks prior to the expected date of calving in transition cows is also common in those countries where this product is registered for this indication. It has been possible to a certain extent to control the incidence and duration of SCK by decreasing blood BHBA concentration (16, $21,39)$. Significantly reduced incidence and duration of SCK measured by serum BHBA $(\geq 1.2 \mathrm{mmol} / \mathrm{L})$ in weeks 1, 2, 4, 6 and 9 post calving was reported after using CRC of monensin at the beginning of close up $(16,21)$. Another study, using a lower threshold of serum BHBA $(\geq 1.0 \mathrm{mmol} / \mathrm{L})$ including milk BHBA $(\geq 200 \mu \mathrm{mol} / \mathrm{L})$ to define SCK, showed similar results for the control of SCK by CRC of monensin within 14 days postpartum (39). Use of monensin results in a continuous decrease in BHBA flow into the blood by decreasing butyrate and increasing propionate concentrations in the rumen at the same time as decreasing free fatty acids in the circulation (21). PG usage is also very common in ketosis or SCK treatment. The positive effect of PG ( $300 \mathrm{~mL}$ oral for 5 days) on the treatment of SCK has been reported. It reduced hyperketonemia incidence and the associated economic impact as well as increased milk production $(20,35)$.

\section{Conclusion}

The TP in dairy cattle remains a critical period in terms of the development of detrimental health disorders unless management precautions are taken at different times (Fig. 1). To monitor the health status during the TP especially in the prepartum period, a recent study by Ruprehter et al. (54) recommended analysis of prepartum albumin and cholesterol concentrations as predictors for metritis, RP and mastitis in multiparous cows with mild NEB in terms of NEFA, BHB and BCS profiles. Rising levels of NEFA and BHBA during the dry period and early lactation are significant predictors for culling risk (51). In this context SCK, a silent and underestimated metabolic disease $(6,9)$, with an 
average prevalence of $22-24 \%$ worldwide $(11,62)$ is easy to detect with a cow-side validated BHBA analyser $(26,29)$ on farms during calving and in early lactation. However, there is currently no validated cow-side device available for the testing of NEFA and haptoglobin. Taking into account various impacts such as reduced milk production (roughly $300 \mathrm{~kg}$ per lactation), increased risk for DA, RP, metritis, mastitis, lameness, prolonged open-period, low conception rate and culling, reports on transition dairy cattle with SCK have indicated significant production losses of between \$200-290 per cow per year. Dairy cattle with significant reduction in DMI are at higher risk of metabolic, reproductive and bacterial diseases. As calving nears (close-up), the percentage of concentrates in the ration should be increased to support milk and colostrum production. Preventive actions, monitoring and adaptive nutrition should be implemented to avoid reduced DMI, fat BCS, NEB, hypocalcaemia, inflammation, oxidative stress and other postpartum diseases associated with SCK, thus avoiding their economic impacts in dairy cattle husbandry.

\section{References}

1. Andersson L.: Subclinical ketosis in dairy cows. Vet. Clin. North. Am. Food Anim. Pract. 1988, 4, 233-251, doi: 10.1016/S0749-0720(15)31046-X.

2. Angelia E., Trionfinia V., Gareisa N. C., Matillera V., Hubera E., Reya F., Salvettia N. R., Ortegaa H. H., Heina G. J.: Protein and gene expression of relevant enzymes and nuclear receptor of hepatic lipid metabolism in grazing dairy cattle during the transition period. Research in Veterinary Science 2019 , 123, 223-231, doi: 10.1016/j.rvsc.2019.01.020.

3. Baumgard L. H., Collier R. J., Bauman D. E.: A 100-Year Review: Regulation of nutrient partitioning to support lactation. J. Dairy Sci. 2017, 100, 10353-10366, doi: 10.3168/jds.2017-13242.

4. Bell A. W: Regulation of organic nutrient metabolism during transition from late pregnancy to early lactation. J. Anim. Sci. 1995, 73, 2804-2819, doi: $10.2527 / 1995.7392804 \mathrm{x}$

5.Berge A. C., Vertenten $G$.: A field study to determine the prevalence, dairy herd management systems, and fresh cow clinical conditions associated with ketosis in western European dairy herds. J. Dairy Sci. 2013, 97, 2145-2154, doi: 10.3168/jds.2013-7163.

6. Bergmann P.: Subclinical ketosis - an underestimated profit killer in dairy cattle. Tierärztliche Umschau 2018, 73, 12, 462-467.

7.Brunner N., Groeger S., Raposo J. C., Bruckmaier R. M., Gross J. J.: Prevalence of subclinical ketosis and production diseases in dairy cows in Central and South America, Africa, Asia, Australia, New Zealand, and Eastern Europe. Translate Basic Science to Industry Innovation 2018, doi: 10.1093/ tas/txy102.

8. Caré S., Trevisib E., Minutib A., Ferrarib A., Loorc J. J., Calamarib L.: Plasma fructosamine during the transition period and its relationship with energy metabolism and inflammation biomarkers in dairy cows. Livestock Science 2018, 216, 138-147, doi: 10.1111/jvim.15049.

9.Deniz A.: Treatment of subclinical ketosis: The silent profit robber. $21^{\text {st }}$ International Congress of Hungarian Association for Buiatrics, Sümeg, Hungary, 11-15 October, 2011. Oral Presentation.

10. Deniz A., Watanapongchati S., Aiumlamai S.: Effect of original combination of butafosfan and vitamin $B_{12}$ and generics from Asia on reproduction parameters in cattle. XXVI World Buiatrics Congress, Santiago, Chile, November 14-18, 2010. P102.

11. Dohoo I. R., Martin S. W.: Subclinical ketosis: Prevalence and associations with production and disease. Can. J. Comp. Med. 1984, 48, 1-5.

12. Drackley J. K.: Biology of dairy cows during the transition period: The final frontier? J. Dairy Sci. 1999, 82, 2259-2273, doi: 10.3168/jds.s00220302(99)75474-3

13. Duffield T. F.: Subclinical ketosis in lactating dairy cattle. Clin. North Am Food Anim. Pract. 2000, 16, 231-253, doi: 10.1016/S0749-0720(15)30103-1.

14. Duffield T. F., Kelton D. F., Leslie K. E., Lissemore K. D., Lumsden J. H.: Use of test day milk fat and milk protein to detect subclinical ketosis in dairy cattle in Ontario. Can. Vet. J. 1997, 38, 713-718.
15. Duffield T. F., Lissemore K. D., McBride B. W., Leslie K. E.: Impact of hyperketonaemia in early lactation dairy cows on health and production. J. Dairy Sci. 2009, 92, 571-580, doi: 10.3168/jds.2008-1507.

16. Duffield T. F., Sandals D., Leslie K. E., Lissemore K., McBride B. W., Lumsden J. H., Dick P., Bagg R.: Efficacy of Monensin for the Prevention of Subclinical Ketosis in Lactating Dairy Cows. J. Dairy Sci. 1998, 81, 2866-2873, doi: 10.3168/jds.S0022-0302(98)75846-1.

17. Fürll M., Deniz A., Westphal B., Illing C., Constable P. D.: Effect of multiple intravenous injections of butaphosphan and cyanocobalamin on the metabolism of periparturient dairy cows. J. Dairy Sci. 2010, 93, 4155-4164, doi: 10.3168/ jds.2009-2914

18. Gohary K., Overton M. W., Von Massow M., LeBlanc S. J., Lissemore K. D., Duffield T. F.: The cost of a case of subclinical ketosis in Canadian dairy herds. Can. Vet. J. 2016, 57, 728-732.

19. Gordon J. L., Duffield T. F., Herdt T. H., Kelton D. F., Neuder L., LeBlanc $S$. $J$ : : Effects of a combination butaphosphan and cyanocobalamin product and insulin on ketosis resolution and milk production. J. Dairy Sci. 2016, 100, 2954-2966, doi: 10.3168/jds.2016-11925.

20. Gordon J. L., LeBlanc S. J., Kelton D. F., Herdt T. H., Neuder L., Duffield T. F.: Randomized clinical field trial on the effects of butaphosphan cyanocobalamin and propylene glycol on ketosis resolution and milk production. J. Dairy Sci. 2017, 100, 3912-3921, doi: 10.3168/jds.2016-11926.

21. Green B. L., McBride B. W., Sandals D., Leslie K. E., Bagg R., Dick P.: The Impact of a Monensin Controlled-Release Capsule on Subclinical Ketosis in the Transition Dairy Cow. J. Dairy Sci. 1999, 82, 333-342, doi: 10.3168/ jds.S0022-0302(99)75240-9.

22. Grimard B., Freret S., Chevallier A., Pinto A., Ponsart C., Humblot P.: Genetic and environmental factors influencing first service conception rate and late embryonic/foetal mortality in low fertility dairy herds. Animal Reproduction Science 2006, 91, 31-44, doi: 10.1016/j.anireprosci.2005.03.003.

23. Grummer R. R.: Impact of changes in organic nutrient metabolism on feeding the transition dairy cow. J. Anim. Sci. 1995, 73, 2820-2833, doi: 10.2527/1995.7392820x

24. Gustafsson A. H., Andersson L., Emanuelson U.: Effect of hyperketonemia, feeding frequency and intake of concentrate and energy on milk yield in dairy cows. Animal Production 1993, 56, 51-60, doi: 10.1017/S0003356100006152.

25. Herdt T. H.: Ruminant adaptation to NEB: Influences on the etiology of ketosis and fatty liver. Vet. Clin. North Am. Food Anim. Pract. 2000, 16, 215-230, doi: 10.1016/S0749-0720(15)30102-X.

26. Iwersen M., Falkenberg U., Voigtsberger R., Forderung D., Heuwieser W. Evaluation of an electronic cow side test to detect subclinical ketosis in dairy cows. J. Dairy Sci. 2009, 92, 1-7, doi: 10.3168/jds.2008-1795.

27. Jordan E. R., Fourdraine R. H.: Characterization of the management practices of the top milk producing herds in the country. J. Dairy Sci. 1993, 76, 3247-3256, doi: 10.3168/jds.S0022-0302(93)77661-4.

28. Kaufman E. I., LeBlanc S. J., McBride B. W., Duffield T. G., DeVries T. J.: Association of rumination time with subclinical ketosis in transition dairy cows. J. Dairy Sci. 2016, 99, 5604-5618, doi: 10.3168/jds.2015-10509.

29. Khol J. L., Freigassner K., Stanitznig A., Tichy A., Wittek T.: Evaluation of a handheld device for the measurement of beta-hydroxybutyrate in capillary blood obtained by the puncture of the vulva as well as in venous whole blood in cattle. Polish Journal of Veterinary Sciences 2019, 22, 557-564, doi: 10.24425/ pjvs.2019.129964.

30. Kolk J. H., Gross J. J., Gerber V., Bruckmaier R. M.: Disturbed bovine mitochondrial lipid metabolism: a review. Veterinary Quarterly 2017, 37, 262-273, doi: 10.1080/01652176.2017.1354561

31. Kremer W. D. J., Noordhuizen-Stassen E. N., Grommers F. J., Schukkken Y. K., Heringa R., Brand A., Burvenich C.: Severity of experimental Escherichia coli mastitis in ketonemic and nonketonemic dairy cows. J. Dairy Sci. 1993, 76, 3428-3436, doi: 10.3168/jds.S0022-0302(93)77681-X.

32. LeBlanc S. J.: Monitoring metabolic health of dairy cattle in the transition period. J. Rep. Dev. 2010, 56, 29-35, doi: 10.1262/jrd.1056s29.

33. LeBlanc $S$. J.: Review: Relationships between metabolism and neutrophil function in dairy cows in the peripartum period. Animal 2020, 14, p. s44-s54, doi: $10.1017 / \mathrm{S} 1751731119003227$.

34. LeBlanc S. J., Leslie K. E., Duffield T. D.: Metabolic predictors of DA in dairy cattle. J. Dairy Sci. 2005, 88, 159-170, doi: 10.3168/jds.S0022-0302(05)72674-6.

35. McArt J. A. A., Nydam D. V., Oetzel G. R.: Epidemiology of subclinical ketosis in early lactation dairy cattle. J. Dairy Sci. 2012, 95, 5056-5066, doi: 10.3168 jds.2012-5443.

36. McArt J. A. A., Nydam D. V., Oetzel G. R., Guard C. L.: An economic analysis of hyperketonemia testing and propylene glycol treatment strategies in early lactation dairy cattle. Preventive Veterinary Medicine. 2014, 117, 170-179, doi: 10.1016/j.prevetmed.2014.06.017. 
37. McArt J. A. A., Nydam D. V., Overton M. W.: Hyperketonemia in early lactation dairy cattle. A deterministic estimate of component and total cost per case. J. Dairy Sci. 2015, 98, 2043-2054, doi: 10.3168/jds.2014-8740

38. McGuffey R. K.: A 100-Year Review: Metabolic modifiers in dairy cattle nutrition. J. Dairy Sci. 2017, 100, 10113-10142, doi: 10.3168/jds.2017-12987.

39. Melendez P., Goff J. P., Risco C. A., Archbald L. F., Littell R., Donovan G. A. Incidence of subclinical ketosis in cows supplemented with a monensin controlled-release capsule in Holstein cattle, Florida, USA. Preventive Veterinary Medicine 2006, 73, 33-42, doi: 10.1016/j.prevetmed.2005.08.022.

40. Mezzetti M., Minuti A., Piccioli-Cappelli F., Amadori M., Bionaz M., Trevisi E.: The role of altered immune function during the dry period in promoting the development of subclinical ketosis in early lactation. J. Dairy Sci. 2019, 102 (10), doi: 10.3168/jds.2019-16497.

41. Miettinen P. V. A., Setala J. J.: Relationships between subclinical ketosis, milk production and fertility in Finnish dairy cattle. Preventive Veterinary Medicine 1993, 17, 1-8, doi: 10.1016/0167-5877(93)90049-Y.

42. Morton J. M., Auldist M. J., Douglas M. L., Macmillan K. L.: Associations between milk protein concentration, milk yield, and reproductive performance in dairy cows. J. Dairy Sci. 2016, 99, 10033-10043, doi: 10.3168/jds.201611275

43. Mostert P. F., Bokkers E. A. M., van Middelaar C. E., Hogeveen H., de Boer I. J. M.: Estimating the economic impact of subclinical ketosis in dairy cattle using a dynamic stochastic simulation model. Animal 2017, 1-10, doi: 10.1017/ $\mathrm{S} 1751731117001306$.

44. Nuber U., Dorland H. A.van., Bruckmaier R. M.: Effects of butafosfan with or without cyanocobalamin on the metabolism of early lactating cows with subclinical ketosis. Journal of Animal Physiology and Animal Nutrition 2016, 100, 146-155, doi: 10.1111/jpn.12332.

45. Oetzel G. R.: Monitoring and testing dairy herds for metabolic disease. Vet Clin. Food Anim. 2004, 20, 651-674, doi: 10.1016/j.cvfa.2004.06.006.

46. Overton T. R., McArt A. A., Nydam D. V: A 100-Year Review: Metabolic health indicators and management of dairy cattle. J. Dairy Sci. 2017, 100, 10398-10417, doi: 10.3168/jds.2017-13054.

47. Putman A. K., Brown J. L., Gandy J. C., Wisnieski L., Sordillo L. M.: Changes in biomarkers of nutrient metabolism, inflammation, and oxidative stress in dairy cows during the transition into the early dry period. J. Dairy Sci. 2018 , 101, 9350-9359, doi: 10.3168/jds.2018-14591.

48. Raboisson D., Mounié M., Khenifar E., Maigné E.: The economic impact of subclinical ketosis at the farm level: Tackling the challenge of over-estimation due to multiple interactions. Prev. Vet. Med. 2015, 122, 417-425, doi: 10.1016/ j.prevetmed.2015.07.010.

49. Raboisson D., Mounié M., Maigné E.: Diseases, reproductive performance, and changes in milk production associated with subclinical ketosis in dairy cows: A meta-analysis and review. J. Dairy Sci. 2014, 97, 7547-7563, doi: 10.3168/jds.2014-8237.

50. Ribeiro E. S., Lima F. S., Greco L. F., Bisinotto R. S., Monteiro A. P. A. Favoreto M., Ayres H., Marsola R. S., Martinez N., Thatcher W. W., Santos $J$. E. P.: Prevalence of periparturient diseases and effects on fertility of seasonally calving grazing dairy cows supplemented with concentrates. J. Dairy Sci. 2013, 96, 5682-5697, doi: 10.3168/jds.2012-6335.

51. Roberts T., Chapinal N., LeBlanc S. J., Kelton D. F., Dubuc J., Duffield T. F.: Metabolic parameters in transition cows as indicators for early-lactation culling risk. J. Dairy Sci. 2012, 95, 3057-3063, doi: 10.3168/jds.2011-4937.

52. Roche J. R., Burke C. R., Crookenden M. A., Heiser A., Loor J. L., Meier S., Mitchell M. D., Phyn C. V. C., Turner S. A.: Fertility and the transition dairy cow. Reproduction, Fertility and Development 2018, 30, 85-100, doi: 10.1071/ RD17412.

53. Rollin E., Berghaus R. D., Rapnicki P., Godden S. M., Overton M. W.: The effect of injectable butaphosphan and cyanocobalamin on postpartum serum $\beta$-hydroxybutyrate, calcium, and phosphorus concentrations in dairy cattle. J. Dairy Sci. 2009, 93, 978-987, doi: 10.3168/jds.2009-2508.

54. Ruprechter G., Adrien M. L., Larriestra A., Meotti O., Batista C., Meikle A., Noro M.: Metabolic predictors of peripartum diseases and their association with parity in dairy cows. Research in Veterinary Science 2018, 118, 191-198, doi: 10.1016/j.rvsc.2018.02.005

55. Rutherford A. J., Oikonomou G., Smith R. F.: The effect of subclinical ketosis on activity at estrus and reproductive performance in dairy cattle. J. Dairy Sci. 2015, 99, 4808-4815, doi: 10.3168/jds.2015-10154

56. Şahal M., Deniz A., Vural R., Kuplulu S., Polat I., Çolakoglu Ç., Ocal N., Macun Ceyhun H., Pekcan M., Ocak M.: Evaluation of the Effect of Different Doses of Butaphosphan and Cyanocobalamin Combination in Dairy Cattle with Subclinical Ketosis. Kafkas Univ. Vet. Fak. Derg. 2017, 23, 349-356, doi: $10.9775 / \mathrm{kvfd} .2016 .16651$

57. Santschi D. E., Lacroix R., Durocher J., Duplessis M., Moore R. K., Lefebvre $D$. $M$ : Cows measured by Fourier-transform infrared analysis in Dairy Herd
Improvement milk samples and association with milk yield and components. J. Dairy Sci. 2016, 99, 9263-9270, doi: 10.3168/jds.2016-11128.

58. Schirmann K., Weary D. M., Heuwieser W., Chapinal N., Cerri R. L., von Keyserlingk M. A.: Short communication: Rumination and feeding behaviors differ between healthy and sick dairy cows during the transition period. J. Dairy Sci. 2016, 99, 9917-9924, doi: 10.3168/jds.2015-10548.

59. Seifi H. A., LeBlanc S. J., Leslie K. E., Duffield T.: Metabolic predictors of post-partum disease and culling risk in dairy cattle. Vet. J. 2011, 188, 216-220, doi: 10.1016/j.tvj1.2010.04.007.

60. Şentürk S., Cihan H., Mecitoğlu Z., Çatık S., Demir G., Kasap S., Topal O.: Prevalence of ketosis in dairy herds in Marmara, Aegean and Mediterranean regions of Turkey. Ankara Üniv. Vet. Fak. Derg. 2016, 63, 283-288.

61. Sheldon I. M.: The postpartum uterus. Vet. Clin. Food Anim. 2004, 20, 569-591, doi: 10.1016/j.cvfa.2004.06.008.

62. Suthar V. S., Canelas-Raposo J., Deniz A., Heuwieser W.: Prevalence of subclinical ketosis and relationships with postpartum diseases in European dairy cows. J. Dairy Sci. 2013, 96, 2925-2938, doi: 10.3168/jds.2012-6035.

63. Urh C., Denißen J., Gerster E., Kraus N., Stamer E., Heitkönig B., Spieker H., Sauerwein H.: Short communication: Pro- and antioxidative indicators in serum of dairy cows during late pregnancy and early lactation: Testing the effects of parity, different dietary energy levels, and farm. J. Dairy Sci. 2019, 102, 6672-6678, doi: 10.3168/jds.2019-16248.

64. Uyarlar C., Cetingül I. S., Gültepe E. E., Sial A. R., Bayram I.: Effects of Subclinical and Clinical Ketosis on The Incidence of Mastitis, Metritis, Culling Rate and Some Hematological Parameters in Dairy Cows. Kocatepe Vet. J. 2018, 11, 186-193, doi: 10.30607/kvj.419839.

65. Ülker H., Bakır G.: Culling Reasons and Affecting Factors in a Holstein Dairy Herd Raised in Southeast Region of Turkey. YYÜ Tar. Bil. Derg. 2013, 23, 134-140.

66. Vanholder T., Papen J., Bemers R., Vertenten G., Berge A. C. B.: Risk factors for subclinical and clinical ketosis and association with production parameters in dairy cows in the Netherlands. J. Dairy Sci. 2015, 98, 880-888, doi: 10.3168/ jds.2014-8362.

67. Walsh R. B., Walton J. S., Kelton D. F., LeBlanc S. J., Leslie K. E., Duffield T. F: The Effect of Subclinical Ketosis in Early Lactation on Reproductive Performance of Postpartum Dairy Cows. J. Dairy Sci. 2007, 90, 2788-2796, doi: $10.3168 /$ jds.2006-560

68. Whitaker D. A., Kelly J. M., Smith E. J.: Subclinical ketosis and serum betahydroxybutyrate levels in dairy cattle. Br. Vet. J. 1983, 139, 462-463, doi: 10.1016/s0007-1935(17)30393-7.

69. Wisnieskia L., Norbya B., Pierceb S. J., Becker T., Gandya J. C., Sordilloa L. $M$.: Predictive models for early lactation diseases in transition dairy cattle at dry-off. Preventive Veterinary Medicine 2019, 163, 68-78, doi: 10.1016/ j.prevetmed.2018.12.014.

Corresponding author: Assoc. Prof. Dr. Abdülkerim Deniz, Department of Biochemistry, Faculty of Veterinary Medicine, Milas, University of Muğla Sıtkı Koçman, Muğla, Turkey; e-mail: abdulkerim.deniz@yahoo.com (ORCID: 0000-0002-5242-5671. Web of Science ResearcherID: M-8478-2018) 